\title{
The use of remote sensing for monitoring Posidonia oceanica and Marine Protected Areas: A systemic review
}

\author{
Luca Appolloni ${ }^{1,2, *}$, Elvira Buonocore ${ }^{1,2}$, Giovanni Fulvio Russo ${ }^{1,2}$, Pier Paolo Franzese ${ }^{1,2}$ \\ ${ }^{1}$ Department of Science and Technology, Parthenope University of Naples, Centro Direzionale, Isola C4, \\ 80143 Naples, Italy \\ ${ }^{2}$ CoNISMa, Piazzale Flaminio 9, 00197 Rome, Italy \\ *corresponding author: luca.appolloni@uniparthenope.it
}

Received: 8 January 2020 / Accepted: 24 February 2020

\begin{abstract}
Posidonia oceanica is a priority habitat (Habitat Directive 92/43/CEE) that needs to be protected by conservation tools such as Marine Protected Areas (MPAs). Remote Sensing (RS) is a useful tool allowing for mapping seagrass meadows and other important marine habitats. In this study, we explore the global scientific literature on RS applied to both P. oceanica and MPAs tracking its evolution and trends by applying network analysis to bibliometric science. The software VOSviewer was used to create maps based on network data of scientific publications displaying relationships among authors and countries. In addition, specific keywords were used to explore the co-occurrence of different terms characterizing the application of RS in marine science. Results showed that France is the main country publishing on RS applied to Posidonia oceanica while Pergent Gérard and Pergent-Martini Cristine resulted the top authors. The co-occurrences analysis highlighted that RS is primarily used for seagrasses mapping, while few studies are focused on their monitoring. Furthermore, investigating RS in connection with MPAs the main country resulted Australia while the top author was Andréfouet. The network map of keywords showed that RS is widely applied to MPAs to study coral reefs and their biodiversity and for mapping marine ecosystems. The use of RS for monitoring Posidonia oceanica beds and MPAs resulted a poorly explored research area, probably due to the low resolution of available data determining large scale habitat mapping. In conclusion, we maintain that RS applications can provide useful information about the effects of local human activities and global climate change on marine ecosystems.
\end{abstract}

Keywords: Remote Sensing, Posidonia oceanica, Marine Protected Area, Bibliometric network analysis, VOSviewer

\section{Introduction}

In the last years, the words "Remote Sensing" (RS) have been used to identify the science of obtaining information based on satellite images useful to monitor terrestrial and marine environments. In particular, in the context of marine environment RS is often used to assess anthropic pressures and environmental indicators through the observation of variables such as Chl-a concentration, Sea Surface Temperature (SST), and salinity (European Commision, 2003; 2010). Chl-a is used to predict algal blooms and assess water quality; indeed, many studies highlight the relationship between water reflectance and algal concentration in freshwater environments and coastal waters (Aulicino et al., 2016; Brezonik et al., 2005; Cotroneo et al., 2016; Gitelson et al., 2000; Han \& Rundquist, 1997; Schalles et al., 1998). Similarly, SST and salinity can be used as indicators of the quality status of key habitats, considering their role in many bio-ecological processes such as reproduction, survival rate, and population dynamic (Fiuza, 1990; Green, 1995; Hedley et al., 2016; Klemas, 2010; Mumby et al., 2004; Santos, 2000).

Recently, RS has also been increasingly used in the monitoring of Marine Protected Areas (MPAs), widely recognized as important tools for protecting marine ecosystems, mitigating human impacts (Appolloni et al., 
2017; Browman \& Stergiou, 2004; Donnarumma et al., 2018; Ferrigno et al., 2016; Halpern et al., 2010; Rassweiler et al., 2012), preserving natural capital stocks (Buonocore et al., 2018, 2019, 2020; Franzese et al., 2017), and producing, at the same time, economic benefits through the sustainable exploitation of natural resources (Franzese et al., 2015; Pauna et al., 2018; Picone et al., 2017). RS applied to MPAs facilitates the observation of wide areas through the interpretation of images showing optical signals most often affordable and available for long time series (Gohin et al., 2008). In particular, Blondeau-Patissier et al. (2014) reviewed the use of statistical techniques applied to satellite optical signals to characterize factors triggering or limiting the development of algal blooms in coastal territories, identifying suitable areas for the establishment of MPAs. Maina et al. (2015) mapped benthic habitats from Tanzania to Kenya through multispectral QuickBird imagery dataset covering about $686 \mathrm{~km}^{2}$ to design a climate-resilient MPAs network. Hedley et al. (2016) investigated the use of RS in MPAs management focusing on different aspects, among which the composition of reefs (in terms of physical extent, benthic cover, bathymetry and rugosity) and environmental parameters (such as SST, exposure, light, and carbonate chemistry). This review concluded that sensor technology and processing algorithms are enhancing habitat mapping through an ever smaller spatial resolution. More recent applications of RS to MPAs can be found in Schulte to Bühne and Pettorelli (2018), Jones et al. (2018), and Merkohasanaj et al. (2019). These studies used RS for investigating different aspects of MPAs, including both ecological variables (e.g., biodiversity, ecological and conservation status) and socioeconomic variables (e.g, MPAs performance).

Another application of RS concerns the use of satellite images for monitoring Posidonia oceanica meadows and their characteristics. P. oceanica is a seagrass, habitat former, that constitutes a biodiversity hotspot and nursery area for many species living on or close to the sea bottom (Boudouresque et al., 2016). P. oceanica is getting an increasing attention in MPAs planning processes (Appolloni et al., 2018a) due to its importance in providing many ecosystem functions and services such as a significant Net Primary Production of both the seagrass and its epibionts, carbon sequestration, and coastal protection (Donnarumma et al., 2014; Mateo et al., 1997; Pergent et al., 2011, 2012; Personnic et al., 2014; Vacchi et al., 2017). In fact, P. oceanica is a priority habitat (Habitat Directive 92/43/CEE) and, together with other habitats such as coralligenous assemblages (Appolloni et al., 2020; Ferrigno et al., 2017), needs to be monitored especially in areas characterized by high urbanization and peculiar physical features. In particular, the monitoring of $P$. oceanica over time allows to estimate the impacts of human activities on the meadows, thus supporting the implementation of conservation ac- tions (Appolloni et al., 2018b, 2018c). Optical-based RS, including both satellite and airborne images, can be very useful to provide knowledge about the spatial distribution and extension of $P$. oceanica, pre-requisite of protection management plans (Borfecchia et al., 2019; Cozza et al., 2019). In this framework, a pioneering research was conducted by Agati et al. (1995) that for the first time used RS and Laser Induced Fluorescience in the monitoring of $P$. oceanica meadows. In the last decades, RS technologies have been improved allowing not only the mapping of P. oceanica (Fornes et al., 2006; Pasqualini et al., 2005) but also the assessment of other variables dealing with the observation of P.oceanica. For example, Borfecchia et al. (2013) used multispectral satellite sensors for monitoring $P$. oceanica in turbid water. Vasilijevic et al. (2014) studied the use of lightweight autonomous underwater vehicles with the RS payload, showing their high performance in terms of economic cost and time. Poursanidis et al. (2018) investigated the potential use of high resolution Earth observations data, allowing the assessment of deep seagrass meadows limits. Finally, Borfecchia et al. (2019) studied the correlation between Leaf Area Index (LAI) of $P$. oceanica and the satellite sensor responses and the corrections needed to reduce aerosol and water column noises.

Considering the importance of RS in support of marine ecosystems conservation and management, it is expected that the scientific literature on these topics will continue increasing over the next years. Bibliometric network analysis has proved to be a useful tool for assessing trends and patterns of scientific literature (Buonocore et al., 2018; Otte \& Rousseau, 2002; Pauna et al., 2018, 2019; Skaf et al., 2020). Coupling bibliometric data and social network analysis, the relationships among researchers, organizations, countries, and keywords dealing with a given topic can be explored (Zou et al., 2018), also allowing the identification of research gaps.

The present study aims at exploring the global scientific literature on RS applied to P. oceanica and Marine Protected Areas, tracking its evolution and trends by applying network analysis to bibliometric science.

\section{Materials and methods}

\subsection{Bibliometric network analysis}

Bibliometric network analysis was performed by using VOSviewer software to investigate the scientific literature on RS applied to $P$. oceanica and MPAs. VOSviewer is based on social network analysis (SNA) allowing the implementation and analysis of maps based on bibliographic data. It can generate different types of outputs; in this study the relationships among researchers, countries, and 
keywords were investigated through the selection of coauthorship and co-occurrence analyses (Van Eck \& Waltman, 2018). The software generates network maps allowing the identification of main authors, countries, and keywords related to a given topic. In the clusters maps, the size of items (e.g., authors, countries, and keywords) is function of "Total Link Strength" (TLS) (i.e., the cumulative strength of the links of an item with others), number of documents (ND), and number of citations (NC). Connections among clusters are represented by curved lines whose thickness is related to the "link strength". In particular, in the case of co-authorship, the link strength is the number of publications that two researchers or countries have "co-authored", while in the case of co-occurrences, it represents the number of times that two keywords are paired. Finally, the map resolution determines the number of clusters, thus the higher is the detail, the higher is the number of displayed clusters.

\subsection{Bibliographic research and data collection}

Documents were collected on January 13th, 2020 by the web search engine Scopus. Two different searching strings were used. The search string composed by the words "remote sensing" AND "Posidonia oceanica" was used to focus on the research of RS applied to P. oceanica. Similarly, the search string composed by the words "remote sensing" AND "Marine Protected Area(*)" was used to focus on the research of RS applied to MPAs. The study was performed considering the time frame 1995-2019, starting from the year of the first publication on RS applied to both $P$. oce- anica and MPAs available in Scopus. The data were exported as .csv files after selecting "Citation Information", "Bibliographic Information", "Abstract and Keywords", and "Include references".

\section{Results and discussion}

\section{1. "Remote sensing" AND "Posidonia oceanica"}

The Scopus database search resulted in 38 publications on "Remote sensing" AND "Posidonia oceanica". The number of publications per year shows an exponential growth in the investigated timeframe $\left(\mathrm{R}^{2}=0.5085\right)$, more marked from 2018 (Fig. 1).

The analysis of authors resulted in 158 items. By default settings of VOSviewer, articles with a number of co-authors greater than 25 and authors not connected to others were excluded. Therefore, a total number of 37 authors are shown in Figure 2a grouped in 5 main clusters. In particular, the top two authors were Pergent Gérard and Pergent-Martini Cristine $(\mathrm{TLS}=42$, links $=31, \mathrm{ND}=7$, $\mathrm{NC}=164)$. The network map in Figure $2 \mathrm{~b}$ highlights the important contribution of Italian authors to the study of $P$. oceanica by means of RS. In addition, Figure $2 \mathrm{~b}$ also highlights a strong connection between France and Arab countries. Italy resulted connected mainly with France and Greece.

The analysis of keywords generated a number of 241 results. Among them, only 39 met the threshold of at least two co-occurrences and were grouped in 4 clusters

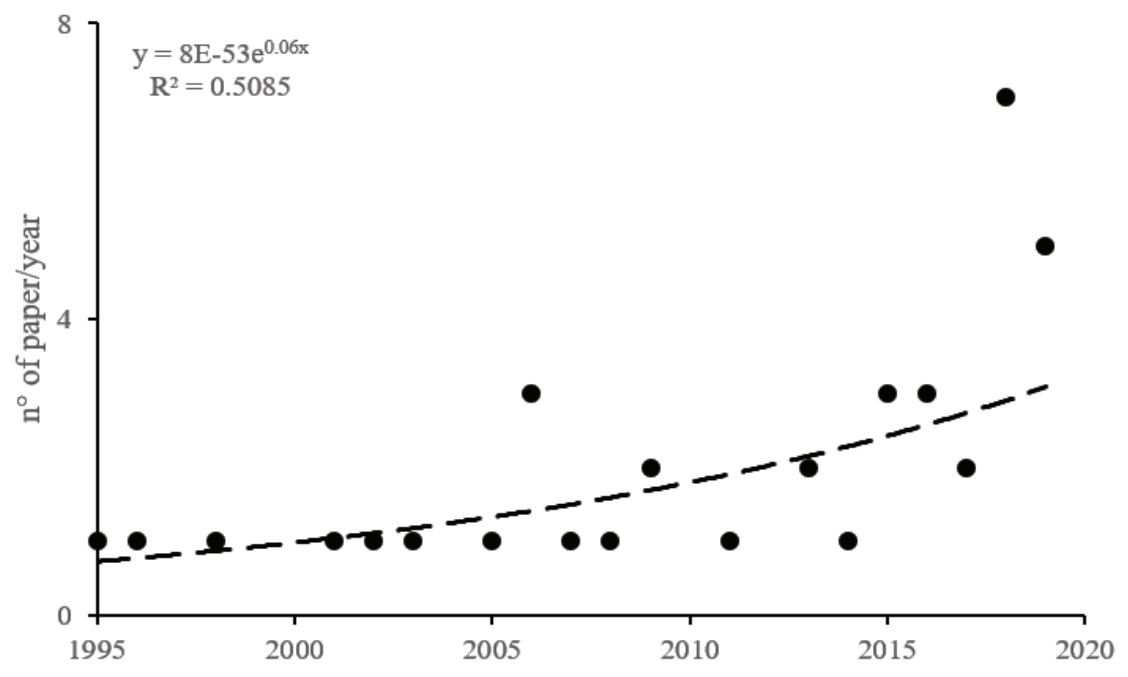

Figure 1. Temporal trend of scientific research on RS applied to P. oceanica published from 1995 to 2019 
(Fig. 3). The top ten keywords listed in Table 1 include "mapping", "ecosystems", and "protected areas". In fact, Figure 3 shows that RS applied to $P$. oceanica is often studied in relation to the mapping of marine ecosystems and their protection through marine protected areas, while a weaker link is shown with the keyword "environmental monitoring". In addition, the network map shows the keyword "Italy" in the same cluster of RS and P. oceanica, highlighting the important contribution of this country to this field of science.

\section{2 "Remote sensing" AND "Marine Protected Area"}

The Scopus database search resulted in 134 publications on "Remote sensing" AND "Marine Protected Area(s)". The number of publications per year shows an exponential growth in the investigated timeframe $\left(\mathrm{R}^{2}=0.7213\right)$, more marked from 2008 (Fig. 4).

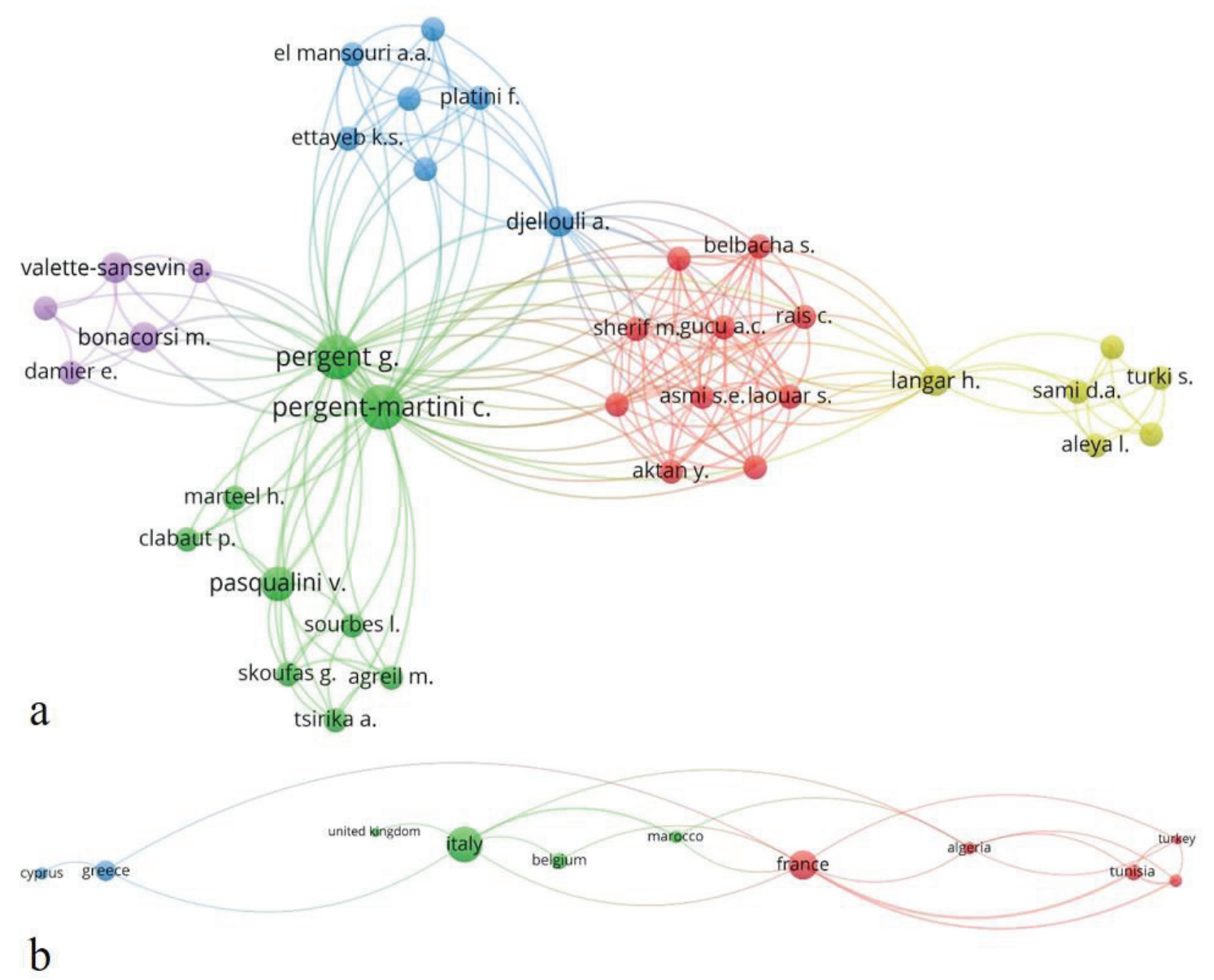

Figure 2. a) Co-authorship network map of authors and b) Co-authorship network map of countries publishing on RS applied to P. oceanica from 1995 to 2019 


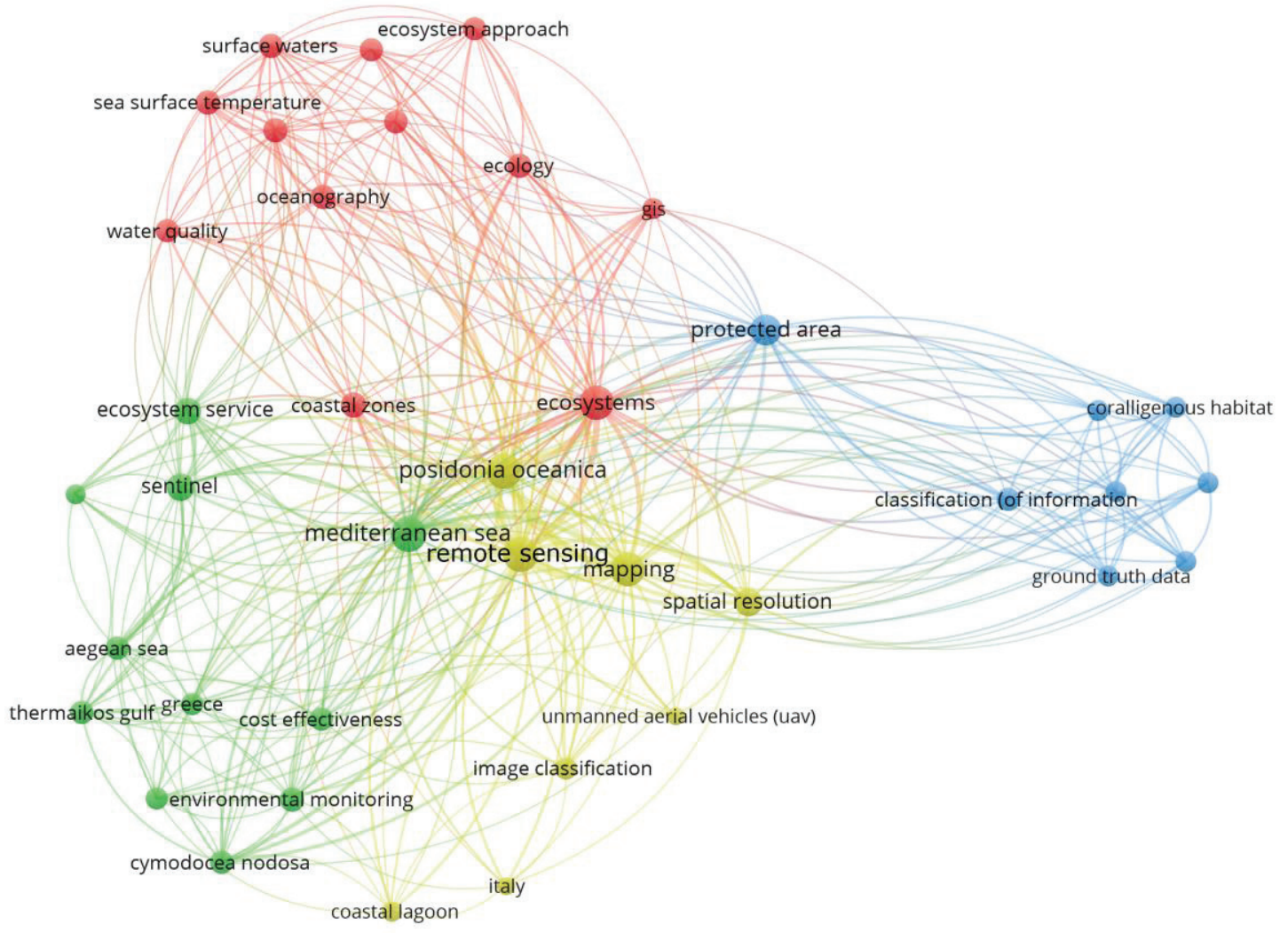

Figure 3. Co-occurrence network map of keywords in studies on RS applied to P. oceanica published from 1995 to 2019

Table 1. Top 10 keywords co-occurring in studies on RS applied to P. oceanica published from 1995 to 2019

\begin{tabular}{|l|c|c|c|}
\hline \multicolumn{1}{|c|}{ Keyword } & Occurrences & TLS & Links \\
\hline Posidonia oceanica & 35 & 158 & 38 \\
\hline Remote sensing & 34 & 100 & 30 \\
\hline Mapping & 20 & 91 & 30 \\
\hline Ecosystems & 18 & 53 & 22 \\
\hline Protected area & 9 & 52 & 17 \\
\hline Mediterranean Sea & 8 & 36 & 14 \\
\hline Spatial resolution & 7 & 11 & 7 \\
\hline Coastal zones & 7 & 4 & 7 \\
\hline Cymodocea nodosa & 6 & 2 & 21 \\
\hline GIS & 5 & & \\
\hline
\end{tabular}




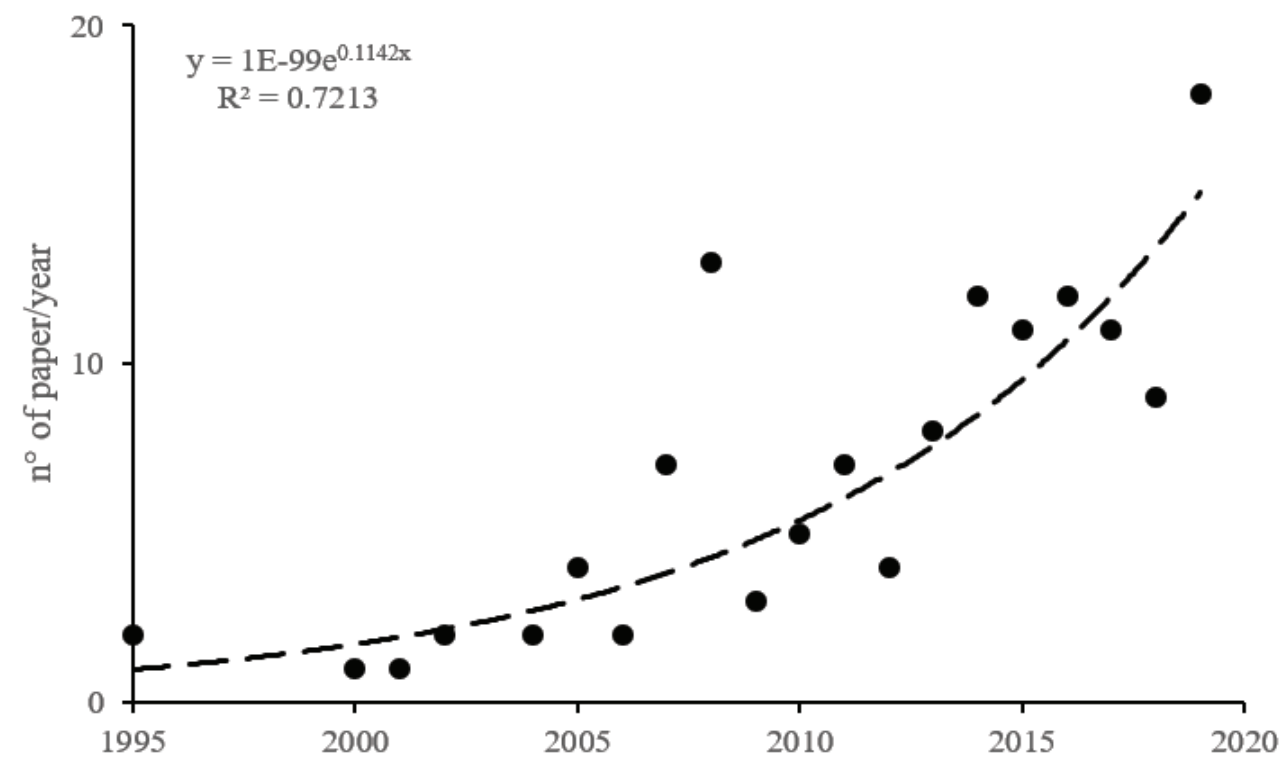

Figure 4. Temporal trend of scientific research on RS applied to MPAs published from 1995 to 2019
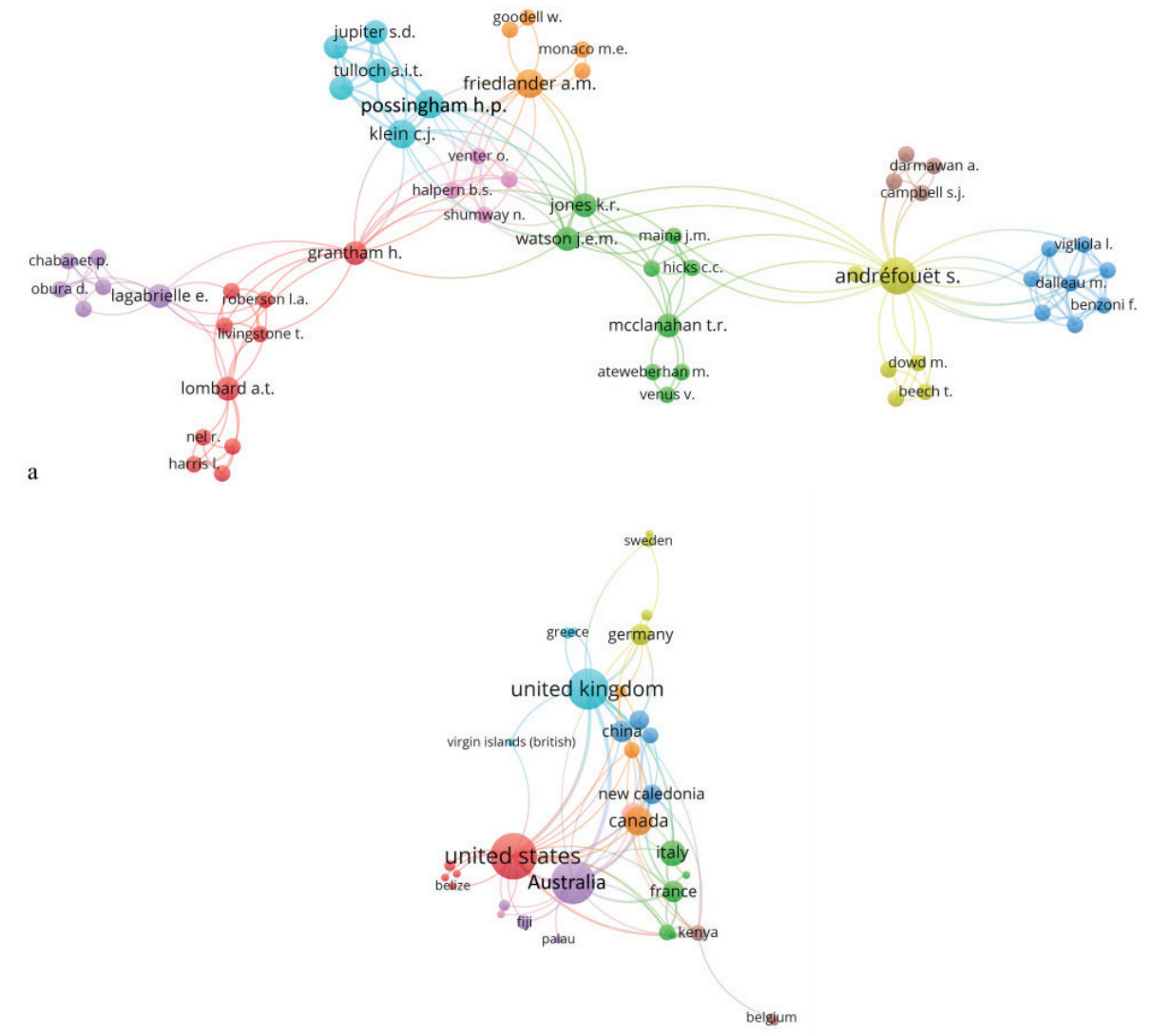

b

Figure 5. a) Co-authorship network map of authors and b) co-authorship network map of countries publishing on RS applied to MPAs from 1995 to 2019 
The analysis of authors resulted in 595 items. By default settings of VOSviewer, articles with a number of coauthors greater than 25 and authors not connected to others were excluded. Therefore, a total number of 58 authors are shown in Figure 5a grouped in 9 main clusters. In particular, the top four authors were: Andréfouet (TLS $=23$, links $=23, \mathrm{ND}=5, \mathrm{NC}=126)$, Possingham $(\mathrm{TLS}=19$, links $=13, \mathrm{ND}=3, \mathrm{NC}=62)$, Friedlander $(\mathrm{TLS}=13$, links $=13, \mathrm{ND}=3, \mathrm{NC}=142)$, and Klein $(\mathrm{TLS}=19$, links $=13, \mathrm{ND}=3, \mathrm{NC}=62$ ), all mainly publishing studies on biodiversity conservation. A deeper analysis of their works shows that RS (often low resolution) is primarily used for large scale habitat mapping without any particular focus on specific habitats such as P.oceanica meadows (Andréfouët \& Hamel, 2014; Beech et al., 2008; Dalleau et al., 2010; Friedlander et al., 2007; Goodell et al., 2018; Jones et al., 2018; Maina et al., 2015; Torres-Pulliza et al., 2013; Tulloch et al., 2017; Wedding \& Friedlander, 2008). The top countries publishing on "Remote sensing" and
"Marine Protected Area" were Australia (TLS = 36, links $=17, \mathrm{ND}=30, \mathrm{NC}=669)$, United States (TLS $=35$, links $=21, \mathrm{ND}=33, \mathrm{NC}=1133)$, and United Kingdom $(\mathrm{TLS}=31$, links $=14, \mathrm{ND}=26, \mathrm{NC}=917$ ) (Fig. 5b).

The analysis of keywords generated a number of 1510 results. Among them, only 53 met the threshold of at least five co-occurrences (Fig. 6). The top ten keywords are listed in Table 2. The map of keywords in Figure 6 highlights that RS is widely applied to MPAs to study coral reefs and their biodiversity and for mapping marine ecosystems, while also in this case a weaker focus is placed on the monitoring of MPAs. Moreover, the "Seagrass" and "Mediterranean Sea" keywords are located in different clusters, indicating a weaker link of studies on RS applied to MPAs focusing on P. oceanica that is endemic of the Mediterranean area. Finally, RS applied to MPAs resulted also connected with fishery management, showing the potential use of RS technologies for investigating illegal fishing in MPAs.

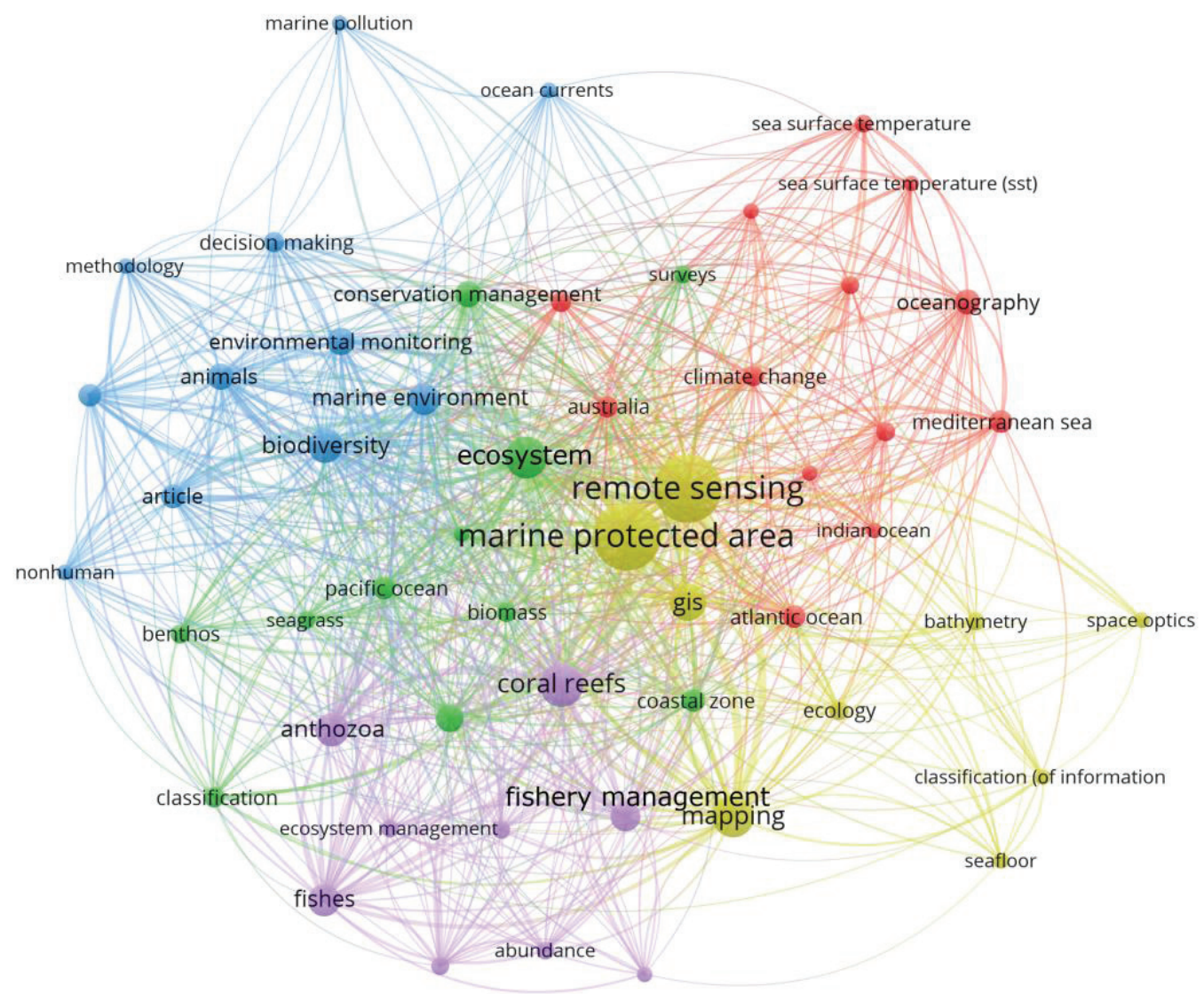

Figure 6. Co-occurrence network map of keywords in studies on RS applied to MPAs from 1995 to 2019 
Table 2. Top 10 keywords co-occurring in studies on RS applied to MPAs from 1995 to 2019

\begin{tabular}{|l|c|l|c|}
\hline \multicolumn{1}{|c|}{ Keyword } & Occurrences & TLS & Links \\
\hline Remote sensing & 108 & 612 & 44 \\
\hline Marine protected area & 109 & 292 & 39 \\
\hline Coral reefs & 40 & 291 & 43 \\
\hline Ecosystem & 38 & 254 & 41 \\
\hline Mapping & 39 & 282 & 39 \\
\hline GIS & 29 & 377 & 31 \\
\hline Biodiversity & 25 & 328 & 30 \\
\hline Anthozoa & 23 & 314 & 27 \\
\hline Fishes & 22 & 280 & 36 \\
\hline Marine environment & 21 & 601 & \\
\hline
\end{tabular}

\section{Conclusions}

This study aims at exploring authors, countries, and keywords in the global scientific literature on RS applied to Posidonia oceanica and MPAs. Although RS is recognized as a very useful technology, its application for the monitoring of $P$. oceanica is still limited. Indeed, RS applications are often limited to the mapping of meadows and habitats and, to date, few studies are related to the monitoring of $P$. oceanica meadows over time. The analysis of RS images over time can provide important information about the effects of local human activities and global climate change on P. oceanica. Similarly, RS is primarily used to map habitats within MPAs and for planning reserves networks, but few studies deal with their monitoring over time. These findings are probably due to the low resolution of affordable RS images not allowing the monitoring at small scales. It is therefore desirable that an increased availability of high resolution RS images (such as the ones generated by WorldView-2) could strengthen the use of RS for the monitoring of marine ecosystems.

\section{Acknowledgements}

The work was supported by the project "Deployable Optics for Remote Sensing Applications - DORA" (ARS01_00653) funded by MIUR - PON "Research \& Innovation"/PNR 2015-2020.

\section{References}

Agati G., Bazzani M., Cecchi G., Mazzinghi P., Pantani L., Raimondi V. \& Settesoldi L., 1995, Remote sensing of Posidonia oceanica by laser induced fluorescence. Int. Geosci. Remote Sens. Symp. 3: 1732-1734.

Andréfouët S. \& Hamel M.A., 2014, Tropical islands quick data gap analysis guided by coral reef geomorphological maps. Mar. Pollut. Bull. 81: 191-199.

Appolloni L., Bevilacqua S., Sbrescia L., Sandulli R., Terlizzi A. \& Russo G.F., 2017, Does full protection count for the maintenance of $\beta$-diversity patterns in marine communities? Evidence from Mediterranean fish assemblages. Aquat. Conserv. Mar. Freshw. Ecosyst. 27: 828-838.

Appolloni L., Ferrigno F., Russo G.F. \& Sandulli R., 2020, $\beta$-Diversity of morphological groups as indicator of coralligenous community quality status. Ecol. Indic. 109: 105840.

Appolloni L., Sandulli R., Vetrano G. \& Russo G.F., 2018a, Assessing the effects of habitat patches ensuring propagule supply and different costs inclusion in marine spatial planning through multivariate analyses. J. Environ. Manage. 214: 45-55.

Appolloni L., Sandulli R., Vetrano G. \& Russo G.F., 2018b, A new approach to assess marine opportunity costs and monetary values-in- use for spatial planning and conservation; the case study of Gulf of Naples, Mediterranean Sea, Italy. Ocean Coast. Manag. 152: 135-144. Appolloni L., Sandulli R., Bianchi C.N. \& Russo G.F., 2018c, Spatial Analyses of An Integrated Landscapeseascape Territorial System: The Case of The Over- 
crowded Gulf of Naples, Southern Italy. J. Environ. Account. Manag. 6: 365-380.

Aulicino G., Cotroneo Y., Lacava T., Sileo G., Fusco G., Carlon R., Satriano V., Pergola N., Tramutoli V. \& Budillon G., 2016, Results of the first Wave Glider experiment in the Southern Tyrrhenian Sea. Adv. Oceanogr. Limnol. 7: 16-35.

Beech T., Dowd M., Field C., Hatcher B. \& Andréfouët S., 2008, A stochastic approach to marine reserve design: Incorporating data uncertainty. Ecol. Inform. 3: 321-333.

Blondeau-Patissier D., Gower J.F.R., Dekker A.G., Phinn S.R. \& Brando V.E., 2014, A review of ocean color remote sensing methods and statistical techniques for the detection, mapping and analysis of phytoplankton blooms in coastal and open oceans. Prog. Oceanogr. 123: $123-144$

Borfecchia F., Consalvi N., Micheli C., Carli F.M., Cognetti De Martiis S., Gnisci V., Piermattei V., Belmonte A., De Cecco L., Bonamano S. \& Marcelli M., 2019, Landsat 8 OLI satellite data for mapping of the Posidonia oceanica and benthic habitats of coastal ecosystems. Int. J. Remote Sens. 40: 1548-1575.

Borfecchia F., Micheli C., Carli F., De Martis S.C., Gnisci V., Piermattei V., Belmonte A., De Cecco L., Martini S. \& Marcelli M., 2013, Mapping Spatial Patterns of Posidonia oceanica Meadows by Means of Daedalus ATM Airborne Sensor in the Coastal Area of Civitavecchia (Central Tyrrhenian Sea, Italy). Remote Sens. 5: 4877-4899.

Boudouresque C.F., Pergent G., Pergent-Martini C., Ruitton S., Thibaut T. \& Verlaque M., 2016, The necromass of the Posidonia oceanica seagrass meadow: fate, role, ecosystem services and vulnerability. Hydrobiologia 781: 25-42.

Brezonik P., Menken K.D. \& Bauer M., 2005, Landsatbased remote sensing of lake water quality characteristics, including chlorophyll and colored dissolved organic matter (CDOM). Lake Reserv. Manag. 21: 373-382.

Browman H.I. \& Stergiou K.I., 2004, Marine Protected Areas as a central element of ecosystem-based management: Defining their location, size and number. Mar. Ecol. Prog. Ser. 274: 271-272.

Buonocore E., Picone F., Russo G.F. \& Franzese P.P., 2018, The Scientific Research On Natural Capital: A Bibliometric Network Analysis. Journal of Environmental Accounting and Management 6(4): 374-384.

Buonocore E., Picone F., Donnarumma L., Russo G.F. \& Franzese P.P., 2019, Modeling matter and energy flows in marine ecosystems using emergy and eco-exergy methods to account for natural capital value. Ecol. Modell. 392: 137-146.

Buonocore E., Appolloni L., Russo G.F. \& Franzese, P.P., 2020, Assessing natural capital value in marine eco- systems through an environmental accounting model: A case study in Southern Italy. Ecol. Modell. 419: 108958

Cotroneo Y., Aulicino G., Ruiz S., Pascual A., Budillon G., Fusco G. \& Tintoré J., 2016, Glider and satellite high resolution monitoring of a mesoscale eddy in the algerian basin: Effects on the mixed layer depth and biochemistry. J. Mar. Syst. 162: 73-88.

Cozza R., Rende F., Ferrari M., Bruno L., Pacenza M., Dattola L. \& Bitonti M.B., 2019, Biomonitoring of Posidonia oceanica beds by a multiscale approach. Aquat. Bot. 156: 14-24.

Dalleau M., Andréfouët S., Wabnitz C.C.C., Payri C., Wantiez L., Pichon M., Friedman K., Vigliola L. \& Benzoni F., 2010, Uso de Hábitats como Sustitutos de la Biodiversidad para la Conservación Eficiente de Arrecifes de Coral. Conserv. Biol. 24: 541-552.

Donnarumma L., Lombardi C., Cocito S. \& Gambi M.C., 2014, Settlement pattern of Posidonia oceanica epibionts along a gradient of ocean acidification: An approach with mimics. Mediterr. Mar. Sci. 15: 498-509.

Donnarumma L., Sandulli R., Appolloni L., Sánchez-Lizaso J.L. \& Russo G.F., 2018, Assessment of Structural and Functional Diversity of Mollusc Assemblages within Vermetid Bioconstructions. Diversity 10: 96-110.

European Commision, 2010, Commision decision 2010/477/EU of 1 September 2010 on criteria and methodological standards on good environmental status of marin waters. OJ L232/14.

European Commission, 2003. Council Recommendation 2002/413/EC of 30 May 2002 concerning the implementation of integrated coastal zone management in Europe. OJ L148/24.

Ferrigno F., Appolloni L., Russo G.F. \& Sandulli R., 2017, Impact of fishing activities on different coralligenous assemblages of Gulf of Naples (Italy). J. Mar. Biol. Assoc. United Kingdom 98: 1-10.

Ferrigno F., Bianchi C.N., Lasagna R., Morri C., Russo G.F. \& Sandulli R., 2016, Corals in high diversity reefs resist human impact. Ecol. Indic. 70: 106-113.

Fiuza A.F.G., 1990, Applications of satellite remote sensing to fisheries, in: Operations Research and Management in Fishing, Springer: 257-279.

Fornes A., Basterretxea G., Orfila A., Jordi A., Alvarez A. \& Tintore J., 2006, Mapping Posidonia oceanica from IKONOS. ISPRS J. Photogramm. Remote Sens. 60: 315-322.

Franzese P.P., Buonocore E., Donnarumma L. \& Russo G.F., 2017, Natural capital accounting in marine protected areas: The case of the Islands of Ventotene and S. Stefano (Central Italy), Ecological Modelling 360: 290-299.

Franzese P.P., Buonocore E., Paoli C., Massa F., Stefano D., Fanciulli G., Miccio A., Mollica E., Navone A., 
Russo G.F., Povero P. \& Vasallo P., 2015, Environmental Accounting in Marine Protected Areas: the EAMPA Project. Journal of Environmental Accounting and Management 3(4): 324-332.

Friedlander A.M., Brown E.K. \& Monaco M.E., 2007, Coupling ecology and GIS to evaluate efficacy of marine protected areas in Hawaii. Ecol. Appl. 17: 715-730.

Gitelson A.A., Yacobi Y.Z., Rundquist D.C., Stark R., Han L. \& Etzion D., 2000, Remote estimation of chlorophyll concentration in productive waters: Principals, algorithm development and validation. Proceedings of NWQMC, National Monitoring Conference: 149-160.

Gohin F., Saulquin B., Oger-Jeanneret H., Lozac'h L., Lampert L., Lefebvre A., Riou P. \& Bruchon F., 2008, Towards a better assessment of the ecological status of coastal waters using satellite-derived chlorophylla concentrations. Remote Sens. Environ. 112: 33293340 .

Goodell W., Stamoulis K.A. \& Friedlander A.M., 2018, Coupling remote sensing with in situ surveys to determine reef fish habitat associations for the design of marine protected areas. Mar. Ecol. Prog. Ser. 588: 121134.

Green J.T., 1995, An assessment of pans as landscape features in the north west province using remote sensing techniques. University of the Witwatersrand, Johannesburg, $106 \mathrm{p}$.

Halpern B.S., Lester S.E. \& McLeod K.L., 2010, Placing marine protected areas onto the ecosystem-based management seascape. Proc. Natl. Acad. Sci. U. S. A. 107: 18312-18317.

Han L. \& Rundquist D.C., 1997, Comparison of NIR/RED ratio and first derivative of reflectance in estimating algal-chlorophyll concentration: A case study in a turbid reservoir. Remote Sens. Environ. 62: 253-261.

Hedley J.D., Roelfsema C.M., Chollett I., Harborne A.R., Heron S.F., Weeks S.J., Skirving W.J., Strong A.E., Mark Eakin C., Christensen T.R.L., Ticzon V., Bejarano S. \& Mumby P.J., 2016, Remote sensing of coral reefs for monitoring and management: A review. Remote Sens. 8: 1-40.

Jones K.R., Klein C.J., Halpern B.S., Venter O., Grantham H., Kuempel C.D., Shumway N., Friedlander A.M., Possingham H.P. \& Watson J.E.M., 2018, The Location and Protection Status of Earth's Diminishing Marine Wilderness. Curr. Biol. 28: 2506-2512.e3.

Klemas V., 2010, Remote Sensing Techniques for Studying Coastal Ecosystems: An Overview. J. Coast. Res. 27: $2-17$

Maina J., Jones K., Hicks C., McClanahan T., Watson J., Tuda A. \& Andréfouët S., 2015, Designing ClimateResilient Marine Protected Area Networks by Combining Remotely Sensed Coral Reef Habitat with Coastal Multi-Use Maps. Remote Sens. 7: 16571-16587.
Mateo M.A., Romeo J., Pérez M., Littler M.M. \& Littler D.S., 1997, Dynamics of millenary organic deposits resulting from the growth of the Mediterranean seagrass Posidonia oceanica. Estuar. Coast. Shelf Sci. 44: 103110.

Merkohasanaj M., Rodríguez-Rodríguez D., García-Martínez M.C., Vargas-Yáñez M., Guillén J. \& Abdul Malak D., 2019, Assessing the environmental effectiveness of the Spanish Marine Reserve Network using remote sensing. Ecol. Indic. 107: 105583.

Mumby P.J., Skirving W., Strong A.E., Hardy J.T., LeDrew E.F., Hochberg E.J., Stumpf R.P. \& David L.T., 2004, Remote sensing of coral reefs and their physical environment. Mar. Pollut. Bull. 48: 219-228.

Otte E. \& Rousseau R., 2002, Social network analysis: A powerful strategy, also for the information sciences. J. Inf. Sci. 28: 441-453.

Pasqualini V., Pergent-Martini C., Pergent G., Agreil M., Skoufas G., Sourbes L. \& Tsirika A., 2005, Use of SPOT 5 for mapping seagrasses: An application to Posidonia oceanica. Remote Sens. Environ. 94: 39-45. Pauna V.H., Picone F., Le Guyader G., Buonocore E. \& Franzese P.P., 2018, The scientific research on ecosystem services: A bibliometric analysis. Ecological Questions 29(3): 53-62.

Pauna V.H., Buonocore E., Renzi M., Russo G.F. \& Franzese P.P., 2019, The issue of microplastics in marine ecosystems: A bibliometric network analysis. Mar. Pollut. Bull. 149: 110612.

Pergent G., Aktan Y., Belbacha S., Djellouli A., De La Grandrive R.D., Elagil E.M.A., El Asmi S., Gucu A.C., Langar H., Laouar S., Pergent-Martini C., Rais C., Semroud R. \& Sherif M., 2011, Setting up the Medposidonia programme in the mediterranean region, [in:] Proc. 10th Int. Conf. Mediterr. Coast. Environ. MEDCOAST 2011, 1: 241-252.

Pergent G., Bazairi H., Bianchi C.N., Boudouresque C.F., Buia M.C., Clabaut P., Harmelin-Vivien M., Mateo M.A., Montefalcone M., Morri C., Orfanidis S., Pergent-Martini C., Semroud R., Serrano O. \& Verlaque M., 2012, Mediterranean seagrass meadows: resilience and contribution to climate change mitigation. A short summary. Gland, Switzerland and Málaga, Spain: IUCN, 40 p.

Personnic S., Boudouresque C.F., Astruch P., Ballesteros E., Blouet S., Bellan-Santini D., Bonhomme P., Thibault-Botha D., Feunteun E., Harmelin-Vivien M., Pergent G., Pergent-Martini C., Pastor J., Poggiale J.C., Renaud F., Thibaut T. \& Ruitton S., 2014, An Ecosystem-Based Approach to Assess the Status of a Mediterranean Ecosystem, the Posidonia oceanica Seagrass Meadow. PLoS ONE 9(6): e98994.

Picone F., Buonocore E., D’Agostaro R., Donati S., Chemello R. \& Franzese P.P., 2017, Integrating natural capital 
assessment and marine spatial planning: A case study in the Mediterranean sea. Ecol. Modell. 361: 1-13.

Poursanidis D., Topouzelis K. \& Chrysoulakis N., 2018, Mapping coastal marine habitats and delineating the deep limits of the Neptune's seagrass meadows using very high resolution Earth observation data. Int. J. Remote Sens. 39: 8670-8687.

Rassweiler A., Costello C. \& Siegel D.A., 2012, Marine protected areas and the value of spatially optimized fishery management. Proc. Natl. Acad. Sci. 109: 1188411889.

Santos A.M.P., 2000, Fisheries oceanography using satellite and airborne remote sensing methods: A review. Fish. Res. 49: 1-20.

Schalles J.F., Gitelson A.A, Yacobi Y.Z. \& Kroenke A.E., 1998, Estimation of chlorophyll a from time series mesurements of high spectral resolution reflectance in an eutrophic lake. Journal of Phycology 34(2): 390: 383-390.

Schulte to Bühne H. \& Pettorelli N., 2018, Better together: Integrating and fusing multispectral and radar satellite imagery to inform biodiversity monitoring, ecological research and conservation science. Methods Ecol. Evol. 9: $849-865$.

Skaf L., Buonocore E., Dumontet S., Capone R. \& Franzese P.P., 2020, Applying network analysis to explore the global scientific literature on food security. Ecological Informatics 56: 101062.

Torres-Pulliza D., Wilson J.R., Darmawan A., Campbell S.J. \& Andréfouët S., 2013, Ecoregional scale seagrass mapping: A tool to support resilient MPA network design in the Coral Triangle. Ocean Coast. Manag. 80: 55-64.

Tulloch V.J., Klein C.J., Jupiter S.D., Tulloch A.I.T., Roelfsema C. \& Possingham H.P., 2017, Trade-offs between data resolution, accuracy, and cost when choosing information to plan reserves for coral reef ecosystems. J. Environ. Manage. 188: 108-119.

Vacchi M., De Falco G., Simeone S., Montefalcone M., Morri C., Ferrari M. \& Bianchi C.N., 2017, Biogeomorphology of the Mediterranean Posidonia oceanica seagrass meadows. Earth Surf. Process. Landforms 42: 42-54.

Van Eck N. J. \& Waltman L., 2018, VOSviewer Manual 1.6.11. Manual, (version 1.6.9).

Vasilijevic A., Miskovic N., Vukic Z. \& Mandic F., 2014, Monitoring of seagrass by lightweight AUV: A Posidonia oceanica case study surrounding Murter island of Croatia, [in:] 22nd Mediterr. Conf. Control Autom. MED 2014: 758-763.

Wedding L.M. \& Friedlander A., 2008, Determining the influence of seascape structure on coral reef fishes in Hawaii using a geospatial approach. Mar. Geod. 31: 246-266.

Zou X., Yue W.L., Vu H.L., 2018, Visualization and analysis of mapping knowledge domain of road safety studies. Accid. Anal. Prev. 118: 131-145. 